\title{
Demystifying a thickened and calcified gall bladder in the era of multimodality imaging
}

\author{
Su Kah Goh, ${ }^{1}$ Anthony Upton, ${ }^{2}$ Christopher Christophi, ${ }^{3}$ Vijayaragavan Muralidharan ${ }^{3}$
}

${ }^{1}$ Department of Surgery, Austin Health, Heidelberg, Victoria, Australia

${ }^{2}$ Capitol Radiology, Vermont South, Victoria, Australia ${ }^{3}$ Department of Surgery, The University of Melbourne, Austin Health, Heidelberg, Victoria, Australia

\section{Correspondence to}

Dr Su Kah Goh,

sukah.goh@austin.org.au

Accepted 4 August 2017

\section{DESCRIPTION}

A 74-year-old woman presented with a 6-month history of significant postprandial nausea and mild abdominal discomfort. She was fit and well with a surgical history of appendicectomy.

Routine blood tests including full blood examination and liver biochemistry were normal. Ultrasonography (US) demonstrated a thickened and calcified gall bladder. This was also confirmed on CT which showed concentric thickening and calcification of the gall bladder wall that was equivocal for an underlying malignancy associated with a large gallstone (figure 1).

Interestingly, further imaging by MRI demonstrated an unexpected but definitive diagnosis of an $8 \mathrm{~cm}$ gallstone within a thin-walled gall bladder (figure 2). Based on the above investigations, an underlying malignant process was considered unlikely and the patient subsequently underwent a laparoscopic cholecystectomy (figure 3).

Her postoperative recovery was uneventful. Histology confirmed cholelithiasis $(8.5 \times 5 \mathrm{~cm}$ gallstone).

Numerous aetiologies such as cholecystitis, adenomyomatosis, congestive cardiac failure and gall bladder cancer can lead to thickening of the

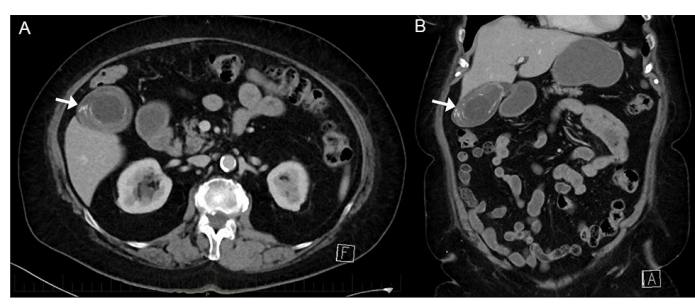

Figure $1 \mathrm{CT}$ in the (A) axial and (B) coronal sections show concentric thickening of the gall bladder wall with minor calcifications associated with cholelithiasis (indicated by the white arrow).

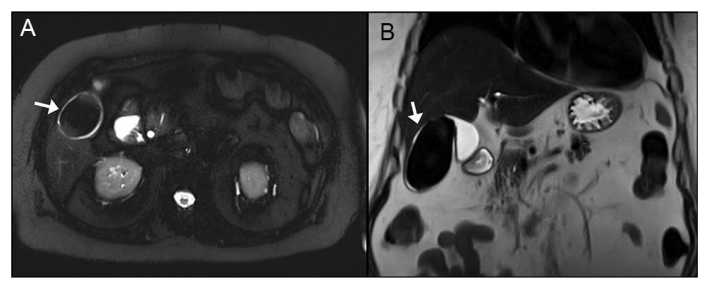

Figure $2 \mathrm{MRI}$ in the $(\mathrm{A})$ axial and (B) coronal sections show a large $8 \mathrm{~cm}$ gallstone in a normal thin-walled gall bladder (indicated by the white arrow).

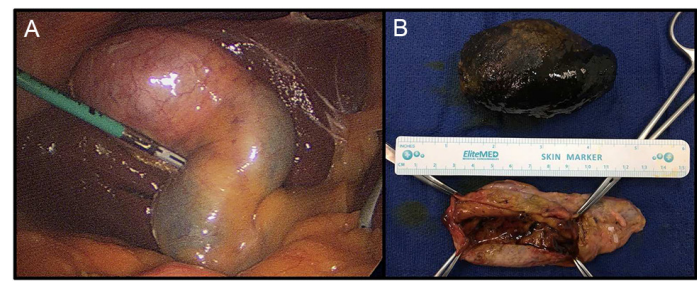

Figure 3 (A) Laparoscopic appearance of the gall bladder prior to the cholecystectomy. (B) Macroscopic appearance of the $8.5 \times 5 \mathrm{~cm}$ gallstone that was retrieved from the gall bladder postoperatively.

\section{Learning points}

- Ultrasonography and CT are initial imaging modality of choice for the evaluation of gall bladder disorders.

- MRI is a useful adjunct that can provide additional features to improve diagnostic accuracy.

gall bladder wall. ${ }^{1}$ The accurate diagnosis of the underlying aetiology is often challenging. US and CT are associated with anatomical and technical pitfalls that can lead to equivocal diagnoses. ${ }^{23}$

In the setting of diagnostic uncertainties (clinically or radiologically), the clinician should consider the use of other imaging modalities for further definitive characterisation. ${ }^{3}$ This case highlights the complementary value of MRI in addition to US and CT for the evaluation of gall bladder disorders in the era of multimodality imaging.

Contributors SKG, AU and VM participated in the clinical care of the patient. SKG wrote the report. AU, CC and VM provided intellectual support for the writing of this report.

Competing interests None declared.

Patient consent Obtained.

Provenance and peer review Not commissioned; externally peer reviewed.

(c) BMJ Publishing Group Ltd (unless otherwise stated in the text of the article) 2017. All rights reserved. No commercial use is permitted unless otherwise expressly granted.

\section{REFERENCES}

1 Runner GJ, Corwin MT, Siewert B, et al. Gallbladder Wall Thickening. Am J Roentgenol 2014;202:W1-W12.

2 Fitzgerald EJ, Toi A. Pitfalls in the ultrasonographic diagnosis of gallbladder diseases. Postgrad Med J 1987;63:525-32.

3 Bilgin M, Shaikh F, Semelka RC, et al. Magnetic resonance imaging of gallbladder and biliary system. Top Magn Reson Imaging 2009;20:31-42. 
Copyright 2017 BMJ Publishing Group. All rights reserved. For permission to reuse any of this content visit http://group.bmj.com/group/rights-licensing/permissions.

BMJ Case Report Fellows may re-use this article for personal use and teaching without any further permission.

Become a Fellow of BMJ Case Reports today and you can:

- Submit as many cases as you like

- Enjoy fast sympathetic peer review and rapid publication of accepted articles

Access all the published articles

- Re-use any of the published material for personal use and teaching without further permission

For information on Institutional Fellowships contact consortiasales@bmjgroup.com

Visit casereports.bmj.com for more articles like this and to become a Fellow 